Check for updates

Cite this: RSC Adv., 2017, 7, 18252

\title{
Cytotoxicity study of polyethylene glycol derivatives
}

Received 20th January 2017 Accepted 18th March 2017

DOI: $10.1039 / \mathrm{c} 7 \mathrm{ra00861a}$

rsc.li/rsc-advances

\author{
Guoqiang Liu, ${ }^{a}$ Yongsan Li, ${ }^{\text {ab }}$ Lei Yang, ${ }^{d}$ Yen Wei, ${ }^{a}$ Xing Wang, ${ }^{b}$ Zhiming Wang $^{\mathrm{c}}$ \\ and Lei Tao (DD *a
}

Polyethylene glycol (PEG) derivatives have been widely used in bio-related research. However, PEG oligomers (with different molecular weights) or PEG based monomers (with different chain end groups) actually have different chemical and physical properties, which might lead to potential toxicity. In this work, the cytotoxicity of a series of PEG derivatives (oligomers and monomers) has been measured using human cervical cancer cells (HeLa) and a cell line of fibroblasts derived from mice (L929) as model cells. Most of the PEG oligomers are safe to both types of cells except triethylene glycol (TEG), which is toxic at high concentrations to $L 929$ cells. On the other hand, PEG-based monomers including poly(ethylene glycol) methyl ether acrylate (mPEGA) and poly(ethylene glycol) methyl ether methacrylate (mPEGMA) showed obvious cytotoxicity. Subsequently, those toxic PEG derivatives have been studied to reveal the different mechanisms of their toxicity. This current research evaluated the cytotoxicity of PEG derivatives and pointed out the potential hazard of 'safe' biomaterials, which might offer a useful reference for people to use the PEG derivatives in future biomedical research.

\section{Introduction}

Polyethylene glycol (PEG) has been widely applied in various medical fields due to its outstanding properties such as satisfactory safety, biocompatibility, hydrophilicity etc. For example, PEG has been used in some Food and Drug Administration approved laxatives because of its excellent moisture retention and lubrication ability. ${ }^{1-3}$ In another example, modifying drugs/ proteins with PEG (PEGylation) can effectively improve their water-solubility and circulation half-life of medicines, ${ }^{\mathbf{4}, 5}$ resulting in enhanced safety and therapy effects. Actually, PEGylation is becoming one of the most attractive biotechnologies and achieving huge success in fundamental research and in the market. ${ }^{6-11}$ By now, many PEG derivatives have been used as excellent starting materials to synthesize a number of new polymeric materials for bioapplications. ${ }^{12}$ For example, a linear PEG has been modified as a difunctionalized PEG (DF-PEG) which could be used to quickly generate an interesting selfhealing hydrogel. ${ }^{\mathbf{1 3 , 1 4}}$ Some PEG oligomers have been used to modify the inorganic nano-particle surface to improve the

${ }^{a}$ Key Laboratory of Bioorganic Phosphorus Chemistry \& Chemical Biology (Ministry of Education), Department of Chemistry, Tsinghua University, Beijing 100084, P. R. China.E-mail: leitao@mail.tsinghua.edu.cn

${ }^{b}$ The State Key Laboratory of Chemical Resource Engineering, Beijing University of Chemical Technology, Beijing 100029, P. R. China

${ }^{c}$ College of Pharmaceutical Science, Zhejiang Chinese Medical University, Hangzhou, Zhejiang 311400, P. R. China

${ }^{d}$ Cancer Institute \& Hospital, Peking Union Medical College \& Chinese Academy of Medical Science, Beijing 100021, P. R. China water-solubility and reduce the toxicity of those inorganic materials. ${ }^{15-17}$ Some commercial PEG-based monomers such as poly(ethylene glycol) methyl ether acrylate (mPEGA) and poly(ethylene glycol) methyl ether methacrylate (mPEGMA) have been used to prepare branched polymers for subsequent protein conjugation, self-assembly, drug delivery etc. ${ }^{18-27}$

Although PEG is normally considered as almost non-toxic, some unsafe problems of PEG with low molecular weights have been noticed by researchers. Smyth et al. reported the chronic oral toxicity of PEG oligomer $\left(M_{\mathrm{n}} \sim 200\right)$ in rats, ${ }^{28,29}$ the adverse results have also be observed in monkeys, ${ }^{30}$ suggesting potential safety problems of these 'safe' materials. Therefore, considered the broad utilization of PEG derivatives in research areas, the systematic cytotoxicity study of those PEG oligomers and PEG-based monomers is necessary and important for their further application in bio-related fields (Scheme 1).

In the current work, cytotoxicity of some PEG oligomers (with different molecular weights) and commercial PEG-based

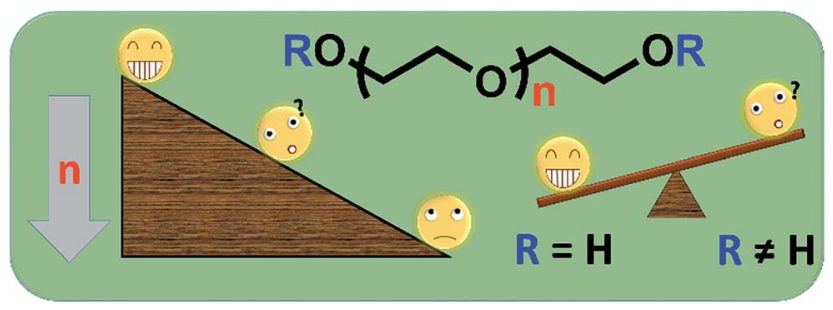

Scheme 1 The possible cytotoxicity of PEG derivatives with different molecular weights and end groups. 
monomers (with different chain end groups) to human cervical cancer cells (HeLa) and a cell line of fibroblast derived from mice (L929) was evaluated. The molecular weight-dependent cytotoxicity of PEG oligomers has been observed, and the different cytotoxicity mechanisms of PEG oligomers and PEGbased monomers were revealed for the first time. Those cytotoxicity information of PEG derivatives might be valuable references for people to choose PEG as starting materials and design purification routes to prepare biocompatible PEG-based materials for further biomedical applications.

\section{Materials and methods}

\subsection{Chemicals}

Triethylene glycol (TEG, 97\%, HEOWNS), PEG-400 $\left(M_{\mathrm{n}} \sim 400\right.$, TCI), PEG-1000 ( $M_{\mathrm{n}} \sim 1000$, Jiangsu Haitian Petrochemical Works), PEG-2000 ( $M_{\mathrm{n}} \sim 2000$, SCRC), PEG-4000 $\left(M_{\mathrm{n}} \sim 4000\right.$, SCRC), poly(ethylene glycol) methyl ether acrylate 480 (mPEGA480, $M_{\mathrm{n}} \sim 480$, Sigma-Aldrich), poly(ethylene glycol) methyl ether methacrylate 500 (mPEGMA-500, $M_{\mathrm{n}} \sim 500$, SigmaAldrich) and poly(ethylene glycol) methyl ether methacrylate 950 (mPEGMA-950, $M_{\mathrm{n}} \sim 950$, Sigma-Aldrich) were used directly without further purification.

Human cervical cancer cells (HeLa) and a cell line of fibroblast derived from mice (L929) were acquired from American type culture collection (ATCC). Dulbecco's modified eagle medium (DMEM, Corning-Cellgro), Phosphate Buffered Saline (PBS, pH 7.2-7.4, $0.01 \mathrm{M}$, Solarbio), fetal bovine serum (FBS, Gibco), Roswell Park Memorial Institute 1640 culture medium (RPMI 1640 culture medium, Gibco), penicillin-streptomycin solution (Gibco), trypsin-EDTA (Gibco, 0.25\%), 4-(3-(2-methoxy4-nitrophenyl)-2-(4-nitrophenyl)-2H-tetrazol-3-ium-5-yl)benzene1,3-disulfonate (CCK-8, Beyotime), 2,7-dichlorodihydrofluorescein diacetate (DCFH-DA, Beyotime), oxidized glutathione (GSSG, Beyotime), nicotinamide adenine dinucleotide phosphate (NADPH, Beyotime), 5,5'-dithiobis-(2-nitrobenzoic acid) (DTNB, Beyotime), fluorescein diacetate (FDA, Sigma) and propidium iodide (PI, 94\%, Sigma) were used as purchased.

\subsection{Cell culture}

Cell culture was maintained in a $37{ }^{\circ} \mathrm{C}$ incubator with $5 \% \mathrm{CO}_{2}$, culture medium was changed every one or two days for maintaining the exponential growth of the cells. HeLa cells were derived from cervical cancer cells and cultured in DMEM medium supplemented with $10 \%$ fetal bovine serum (FBS) and 1\% penicillin and streptomycin. L929 cells were derived from mice and cultured in RPMI 1640 medium supplemented with $10 \%$ fetal bovine serum (FBS) and $1 \%$ penicillin and streptomycin.

\subsection{Cytotoxicity analysis}

2.3.1 Cell viability assay. The cell viability assays of PEG oligomers and three PEG-based monomers to HeLa and L929 cells were evaluated using cell count kit-8 (CCK-8), ${ }^{31}$ an improved version of the MTT assay (measuring the cleavage of the tetrazolium ring and formation of the formazan in living cells). Typically, cells were seeded in a 96-well plate at a density of $\sim 5 \times 10^{4}$ cells per $\mathrm{mL}$ in $100 \mu \mathrm{L}$ of respective media containing 10\% FBS and 1\% penicillin and streptomycin. After attachment, cells were washed with PBS and cultured with different concentration of PEG derivatives in culture medium for $24 \mathrm{~h}$, then washed three times with PBS. The treated cells were cultured in $100 \mu \mathrm{L}$ of medium with $10 \%$ CCK- 8 solution at $37{ }^{\circ} \mathrm{C}$ for $2 \mathrm{~h}$, then analysed using a microplate reader (VICTOR $^{\text {TM }}$ X3 PerkinElmer 2030 Multilabel Plate Reader). The dye absorbance was measured under $450 \mathrm{~nm}$ and the reduction of CCK-8 dye was compared to positive control (cells in pure culture medium, $100 \%$ CCK- 8 dye reduction) and negative control (no cells in plate, $0 \%$ CCK- 8 dye reduction), the absorbance ratio to the positive control and negative control reflects the cell viability.

The results were presented as mean \pm standard deviation (SD), and the half maximal inhibitory concentration 50\% (IC50) values of PEG derivatives were calculated by SPSS 15.0.

2.3.2 Cell morphology observation. L929 cells were seeded in a 24-well plate at a density of $\sim 5 \times 10^{4}$ cells per mL. After attachment, cells were washed with PBS and cultured with cell culture medium containing different concentration of PEG derivatives for $24 \mathrm{~h}$. Then, the cell morphology changes of L929 cells exposed to PEG derivatives were observed using an optical microscopy (Leica Germany).

According to our previous work, ${ }^{32,33}$ fluorescein diacetate (FDA) and propidium iodide (PI) could be used as a rapid and convenient double-staining method to observe the cell viability. L929 cells were seeded in a 24 -well plate at a density of $\sim 5 \times 10^{4}$ cells per mL. After attachment, cells were washed with PBS and cultured with different concentration of PEG derivatives in culture medium for $24 \mathrm{~h}$. Then, the medium was removed, the cells were washed with PBS. A PBS-FDA-PI mixed solution (FDA: $3 \mu \mathrm{g} \mathrm{mL}{ }^{-1}$; PI: $3 \mu \mathrm{g} \mathrm{mL}^{-1}$ ) was subsequently added and the 24 -well plate was incubated at $37{ }^{\circ} \mathrm{C}$ for $15 \mathrm{~min}$. A fluorescence microscope (Leica Germany) was used to observe the live and dead cells under 450-490 $\mathrm{nm}$ and 515-560 $\mathrm{nm}$ band-pass excitation filters (I3 and N2.1), respectively (100 W mercury lamp).

2.3.3 Radical oxygen assay (ROS) generation. Intracellular oxidative stress from PEG oligomers and monomers is displayed as the level of ROS. 2,7-Dichlorodihydrofluorescein diacetate (DCFH-DA) was used to measure the generation of ROS. ${ }^{34}$ Typically, L929 cells were seeded in a 96-well plate, after removing the culture medium, the cells were washed with PBS and cultured in $100 \mu \mathrm{L}$ of working solution containing $\mathrm{DCFH}-$ DA $\left(10 \mu \mathrm{mol} \mathrm{L}{ }^{-1}\right)$ at $37{ }^{\circ} \mathrm{C}$ for $1 \mathrm{~h}$. Then, the cells were washed with PBS three times and incubated in culture medium containing different concentration TEG or mPEGA-480 for 0.5, $1,1.5$ and $2.0 \mathrm{~h}$, respectively. The changes of the fluorescein in cells $(485 \mathrm{~nm} / 535 \mathrm{~nm})$ were collected by a microplate reader (VICTOR ${ }^{\mathrm{TM}}$ X3 PerkinElmer 2030 Multilabel Plate Reader). The fluorescence intensity of cells in pure culture medium was used as a control, the values of ROS generation were shown as relative fluorescence intensity compared with the control and presented as mean $\pm \mathrm{SD}$. 
2.3.4 Reduced glutathione (GSH) declined. 5,5'-Dithiobis(2-nitrobenzoic acid) (DTNB) was used to measure the reduced glutathione levels. All steps were in accordance with the manufacturer's instruction.

Briefly, L929 cells were seeded in a 24-well plate and incubated in $0.5 \mathrm{~mL}$ of culture medium with different concentration of TEG (A, $\left.\mathrm{A}^{\prime}\right)$ for $1 \mathrm{~h}$ (Fig. 1), A1-A6 wells were used to measure the total amount of glutathione (GSH + GSSG) while $\mathrm{A}^{\prime} 1-\mathrm{A}^{\prime} 6$ wells were used to measure the amount of oxidized glutathione (GSSG) in the presence of TEG. After $1 \mathrm{~h}$, cells were collected by trypsin digestion and centrifugation $(1000 \mathrm{rpm}$, $5 \mathrm{~min})$. Then, treble volume protein removal solution $(50 \mathrm{mg}$ $\mathrm{mL}^{-1}$ ) was added to remove the noisy proteins. After thrice quick freezing-thawing cycles in liquid nitrogen and a $37{ }^{\circ} \mathrm{C}$ water-bath, the suspension were placed in a refrigerator $\left(4^{\circ} \mathrm{C}\right)$ for $5 \mathrm{~min}$, and the samples of cell supernatant were obtained after centrifugation (10000 rpm, $10 \mathrm{~min})$. Samples from A1-A6 wells were used to measure the total glutathione (GSH + GSSG) level. NADPH solution $\left(0.5 \mathrm{mg} \mathrm{mL}{ }^{-1}\right)$ was added to reduce all of glutathione to GSH, then, 5,5'-dithiobis-(2-nitrobenzoic acid) (DTNB) was used to oxidize the GSH, the changed absorbance at $405 \mathrm{~nm}$ was recorded by a microplate reader (VICTOR ${ }^{\mathrm{TM}}$ X3 PerkinElmer 2030 Multilabel Plate Reader) ${ }^{35,36}$ Samples from A'1-A'6 wells were used to measure the oxidized glutathione (GSSG) level. By using the GSH remover solution, only GSSG was left in the sample solution. The samples were analysed through same method as above to measure the GSSG's level. The total glutathione amount and the oxidized glutathione amount were collected to calculate the level of reduced glutathione while the GSH level of cells in pure culture medium was used as the control. The results were presented as mean $\pm \mathrm{SD}$.

Wells in line $\mathrm{B}$ and $\mathrm{B}^{\prime}$ were used to test the total amount of GSH and GSSG in the presence of mPEGA-480, respectively, through the same procedure.

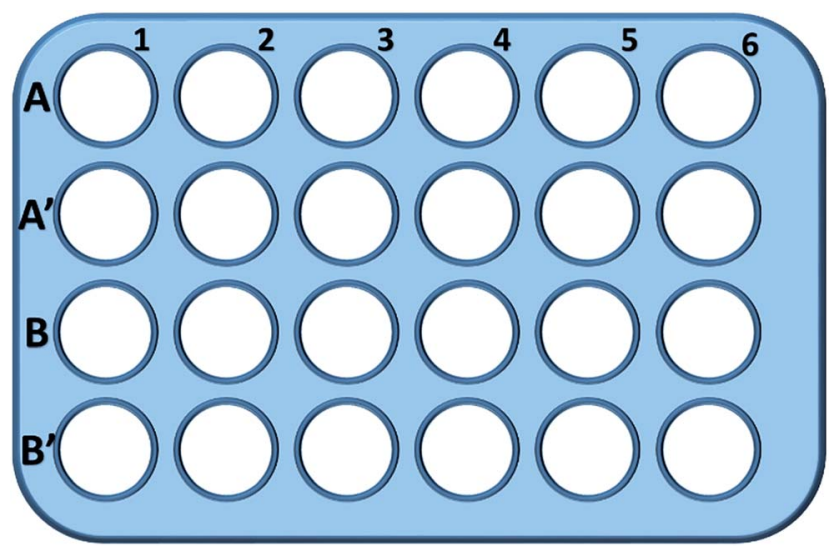

Fig. 1 The configuration of the 24-well plate for GSH analysis. Cells in line 1 were cultured in pure culture medium and used as the control; cells in $A 2-A 6$ and $A^{\prime} 2-A^{\prime} 6$ wells were cultured with $1,2,5,10$ and $20 \mathrm{mg} \mathrm{mL}^{-1}$ of TEG, respectively; cells in $\mathrm{B} 2-\mathrm{B} 6$ and $\mathrm{B}^{\prime} 2-\mathrm{B}^{\prime} 6$ wells were cultured with $1,2,5,10$ and $20 \mathrm{mg} \mathrm{mL}^{-1}$ of mPEGA-480, respectively.

\section{Results and discussion}

\subsection{Cell viability study}

3.1.1 Cell viability in the presence of PEG oligomers. The influence of PEG oligomers (with different molecular weights) on cell growth and viability was examined by $24 \mathrm{~h}$ incubation of HeLa or L929 cells in different concentration PEG solutions.

When HeLa cell (a model of cancer cells) was used (Fig. 2A), the cytotoxicity of all PEG oligomers at low concentrations ( $\leq 5 \mathrm{mg} \mathrm{mL}{ }^{-1}$ ) could be neglected. With increased concentration ( $\geq 10 \mathrm{mg} \mathrm{mL}^{-1}$ ), the molecular weight-dependent cytotoxicity of PEG samples was observed. The triethylene glycol (TEG) showed obvious cytotoxicity over $10 \mathrm{mg} \mathrm{mL}^{-1}(p<0.05$; contrast with any other oligomer when concentration is over $5 \mathrm{mg} \mathrm{mL}^{-1}$ ) and the IC50 value of the TEG to HeLa cells was calculated as $19.8 \mathrm{mg} \mathrm{mL}{ }^{-1}$. Meanwhile, other PEG oligomers $\left(M_{\mathrm{n}} \sim 400-\right.$ 4000) also showed tiny cytotoxicity.

The cytotoxicity of PEG oligomers to L929 cells (a model of normal cells) was also evaluated (Fig. 2B). The cell viability
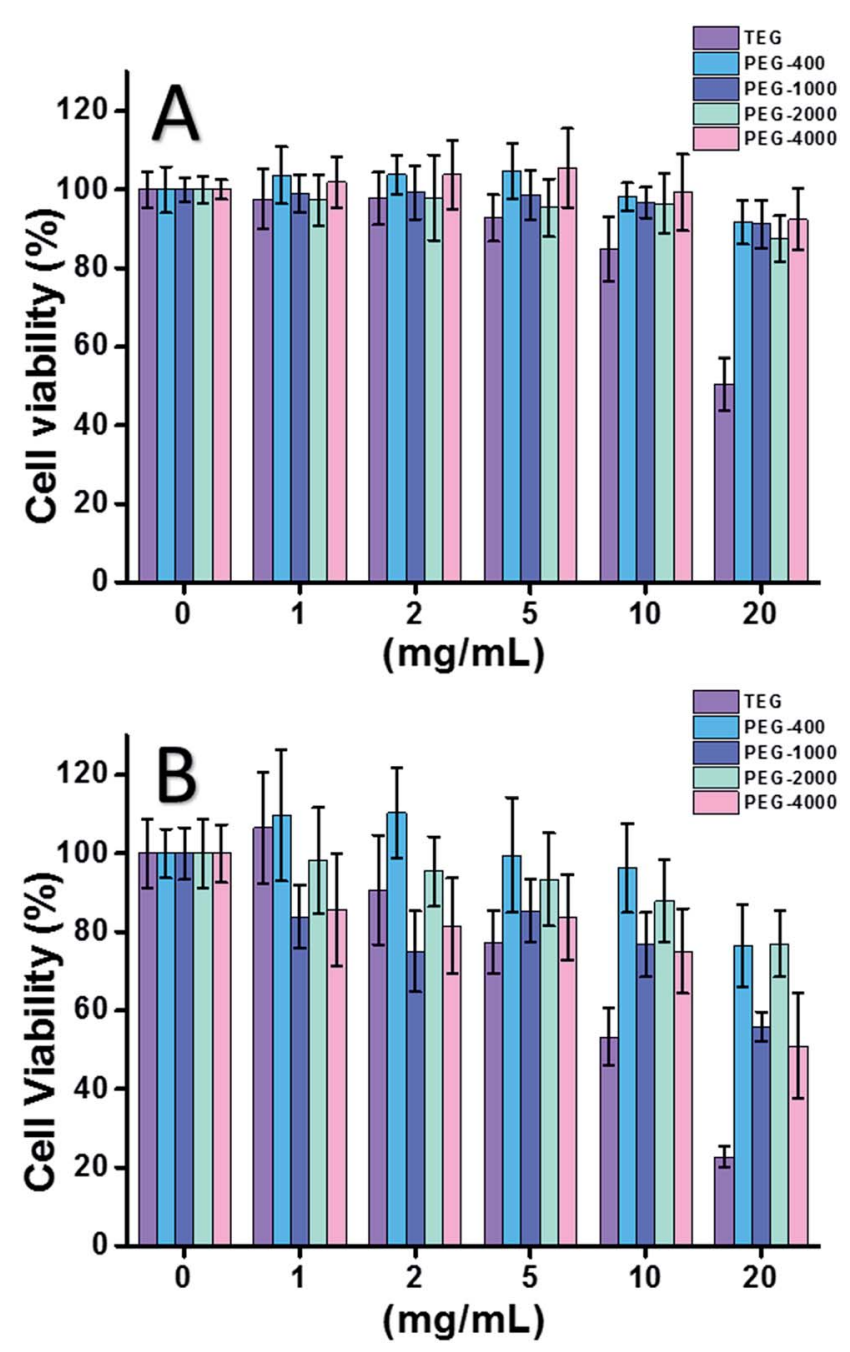

Fig. 2 Concentration-dependent cytotoxicity of PEG oligomers to HeLa cells (A) and L929 cells (B), the concentrations of PEG range from 1 to $20 \mathrm{mg} \mathrm{mL}^{-1}$. Cells in pure culture medium served as the positive control and no cells as negative control. 
decreased with increased PEG concentration as expected. Besides TEG, some PEG oligomers (PEG-1000, PEG-4000) which are safe to HeLa cells also showed detectable cytotoxicity, the IC50 values of TEG, PEG-1000 and PEG-4000 were calculated as $12.4,22.5$, and $20.0 \mathrm{mg} \mathrm{mL} \mathrm{m}^{-1}$ to $\mathrm{L} 929$ cells, respectively, also indicating the molecular weight-dependent cytotoxicity of PEG oligomers.

Above results suggested that HeLa cells have better tolerance to PEG oligomers than L929 cells due to the tenacious vitality of cancer cells, and the TEG has much higher cytotoxicity than other PEG oligomers with higher molecular weights $(p<0.05$; contrast with any other oligomer when concentration is over $5 \mathrm{mg} \mathrm{mL}^{-1}$ ). It is noticed the current research demonstrated the moderate cytotoxicity of PEG-1000 and PEG-4000 to L929 cells, and the nearly non-cytotoxicity of PEG-400 and PEG-2000, which is different with the common impression that high molecular weight PEGs should be more biocompatible than their low molecular weight counterparts. Although the reason of PEG's cytotoxicity is still not clear, PEG-400 and PEG-2000 seem to be better choices for people to synthesize biocompatible materials.

3.1.2 Cell viability in the presence of PEG-based monomers. PEG-based monomers, such as mPEGA-480, mPEGMA500 and mPEGMA-950 have been frequently used in polymer chemistry to synthesize polyPEGs for biomedical applications. The cytotoxicity of some polyPEGs has been detailed studied to screen a safe polymerization route. ${ }^{37-42}$ However, the very important cytotoxicity information of PEG-based monomers has not been fully studied. Thus, we hoped to systematically study the cytotoxicity of PEG-based monomers. The same procedure (CCK- 8 assay) was employed to compare the percent reduction of CCK- 8 dye with positive control (cells in pure culture medium) and negative control (no cells in plate), the influence of three PEG-based monomers on the growth and viability of HeLa and L929 cells was examined after $24 \mathrm{~h}$ incubation.

When mPEGMA-500 was tested, the cell viability of both HeLa cells and L929 cells decreased with increased concentration of mPEGMA-500 (Fig. 3A), and no apparent difference between two types of cells was observed. The IC50 values of mPEGMA-500 are $4.7 \mathrm{mg} \mathrm{mL}^{-1}$ to HeLa cells, and $5.3 \mathrm{mg} \mathrm{mL}^{-1}$ to L929 cells after $24 \mathrm{~h}$ culture, indicating more significant cytotoxicity of mPEGMA-500 than abovementioned PEG oligomers, and implying the chain end groups of PEG derivatives are crucial to their toxicity. When mPEGMA-950, another PEGbased methacrylate with same chain end group but higher molecular weight was tested through same procedure (Fig. 3B), much lower cytotoxicity of mPEGMA-950 to HeLa cells or L929 cells was observed ( $p<0.05$; when concentration is over $2 \mathrm{mg}$ $\mathrm{mL}^{-1}$ ), the IC50 values of mPEGMA-950 are $20.8 \mathrm{mg} \mathrm{mL}^{-1}$ to HeLa cells, and $21.7 \mathrm{mg} \mathrm{mL}^{-1}$ to L929 cells after $24 \mathrm{~h}$ culture, also demonstrating the molecular weight-dependent cytotoxicity of PEG-based methacrylate.

Furthermore, PEG-based acrylate mPEGA-480 was also tested. Although the difference between MPEGA-480 and mPEGMA-500 is only a methyl group at chain end, mPEGA-480 showed acute cytotoxicity (Fig. 3C). More than 95\% cells lost viability even with $1 \mathrm{mg} \mathrm{mL} \mathrm{mLEA}^{-1}$ m80 in the culture
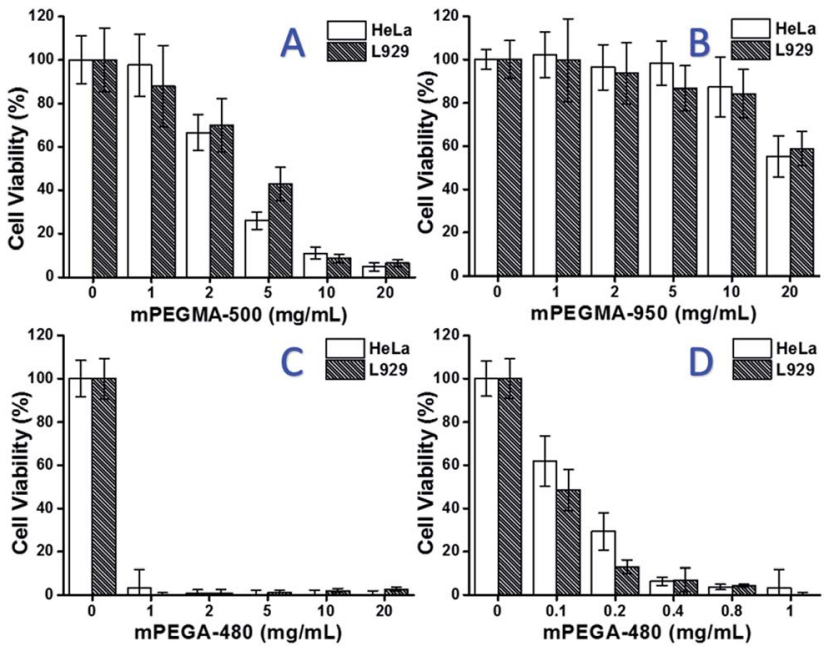

Fig. 3 Concentration-dependent cytotoxicity of mPEGMA-500 (A), mPEGMA-950 (B) and mPEGA-480 (C and D) to HeLa cells and L929 cells, the concentrations of $\mathrm{mPEGMA}$ range from 1 to $20 \mathrm{mg} \mathrm{mL}^{-1}$, the concentrations of $\mathrm{mPEGA}$ range from 0.1 to $20 \mathrm{mg} \mathrm{mL}^{-1}$. Cells without PEG-based monomers served as the positive control and no cells as negative control.

medium. Thus, additional experiments have to be carried out with lower concentrations to determine its cytotoxicity (Fig. 3D), and the IC50 values of mPEGA-480 were calculated as $0.2 \mathrm{mg}$ $\mathrm{mL}^{-1}$ to HeLa cells and $0.1 \mathrm{mg} \mathrm{mL} \mathrm{mL}^{-1}$ to 929 cells after $24 \mathrm{~h}$ culture.

The cell viability experiments confirmed that both chain end groups and molecular weight are important influence elements to the cytotoxicity of PEG derivatives, and the PEG-based monomers showed much more noticeable cytotoxicity compared with PEG oligomers.

Meanwhile, the cytotoxicity of inhibitors in PEG-based monomers, hydroquinone methyl ether (MEHQ, $100 \mathrm{ppm}$ in mPEGA) and butylated hydroxytoluene (BHT, $300 \mathrm{ppm}$ in mPEGMA), were also evaluated (Fig. 4), and the L929 cells remained high viability ( $\geq 90 \%$ ) at low concentrated inhibitors $\left(\leq 1 \mu \mathrm{g} \mathrm{mL}{ }^{-1}\right)$. There are $0.1 \mu \mathrm{g} \mathrm{mL}^{-1}$ of MEHQ in $1 \mathrm{mg} \mathrm{mL}^{-1}$ of mPEGA-480, and $3 \mu \mathrm{g} \mathrm{mL} \mathrm{m}^{-1}$ of BHT in $10 \mathrm{mg} \mathrm{mL}^{-1}$ of mPEGA500, while mPEG-480 and mPEGMA-500 demonstrated obvious
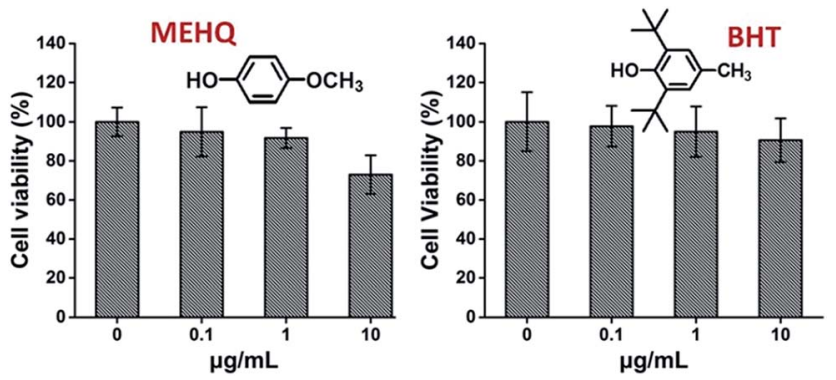

Fig. 4 Concentration-dependent cytotoxicity of two inhibitors include MEHQ and BHT to $\mathrm{L} 929$ cells, the concentrations of inhibitors range from 0.1 to $10 \mu \mathrm{g} \mathrm{mL} \mathrm{L}^{-1}$. Cells without inhibitor served as the positive control and no cells as negative control. 
cytotoxicity at those concentrations. Thus, the trace amount inhibitors in PEG-based monomers seemed have negligible influence on the cytotoxicity of monomers.

\subsection{Cell morphology observation}

Optical microscope observation was used to directly evaluate the cytotoxicity of PEG derivatives to L929 cells. The optical images of $\mathrm{L} 929$ cells exposed to $20 \mathrm{mg} \mathrm{mL}^{-1}$ TEG and $0.1 \mathrm{mg}$ $\mathrm{mL}^{-1}$ mPEGA for $24 \mathrm{~h}$ were shown in Fig. $5 \mathrm{~A}$ and B, respectively.

After incubation with $20 \mathrm{mg} \mathrm{mL}{ }^{-1}$ TEG for $24 \mathrm{~h}$, the cells kept the similar morphology (Fig. 5A) with the control group (Fig. 5C, cells in pure culture medium), but the cell number dramatically decreased, indicating the cytotoxicity of TEG at high concentration, which led to the death and followed detachment of cells from the microplate bottom. Fig. 5B showed the morphology of L929 cells after incubation with $0.1 \mathrm{mg} \mathrm{mL}{ }^{-1}$ mPEGA-480. Almost all cells lost normal morphology, suggesting the acute cytotoxicity of mPEGA-480 even at such a low concentration.

Additionally, the cells were also stained using fluorescein. FDA/PI double-staining is a rapid, simple and simultaneous procedure to observe the living and dead cells. ${ }^{43}$ FDA can enter the complete cells and accumulate in cells, therefore, the complete cell membrane is necessary to prevent the leaking of fluorescein from the cell. In contrast, PI can't pass through the intact cell membrane, but can stain the nucleus of dead cells by passing through the damaged cell membrane. As the Fig. 6 showed, L929 cells incubated with $20 \mathrm{mg} \mathrm{mL} \mathrm{mL}^{-1}$ TEG have less viable cells after the FDA staining (Fig. 6b) compared with the control (Fig. 6a), and more dead cells can be observed after the PI staining (Fig. $6 b^{\prime}$ ), identical with the result by observation through an optical microscopy. mPEGA-480's acute cytotoxicity was also be observed after the FDA/PI double-staining procedure, no green signal could be identified after incubating cells with $0.1 \mathrm{mg} \mathrm{mL}{ }^{-1}$ mPEG-480 for $24 \mathrm{~h}$ (Fig. $6 \mathrm{c}$ and $\mathrm{c}^{\prime \prime}$ ).

Both optical and fluorescent images intuitively demonstrated the cytotoxicity of those PEG derivatives, further supporting the conclusion obtained through CCK-8 assays. It is noticed the mPEGA-480 seemed more toxic by the FDA/PI double staining assay, which is attributed to the FDA/PI double staining distinguishes the completeness of live/dead cell membrane while the CCK-8 assay detects the activity of the dehydrogenase in mitochondria, suggesting FDA/PI staining an excellent supplement of CCK-8 assay to offer more details of the cell status.
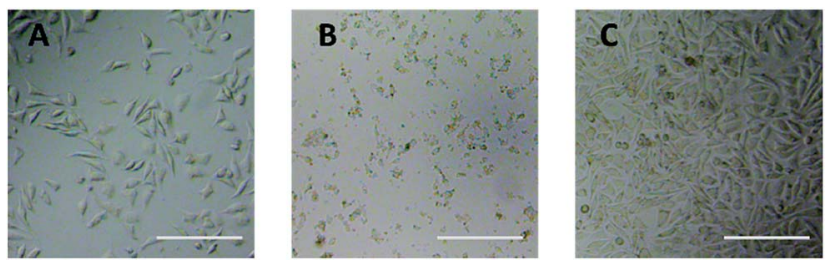

Fig. 5 Optical microscope images of L929 cells incubated with $20 \mathrm{mg}$ $\mathrm{mL}^{-1}$ TEG (A) and $0.1 \mathrm{mg} \mathrm{mL}^{-1} \mathrm{mPEGA}-480$ (B) for $24 \mathrm{~h}$, and the cells in pure culture medium (C, control group). Scale bar $=200 \mu \mathrm{m}$.
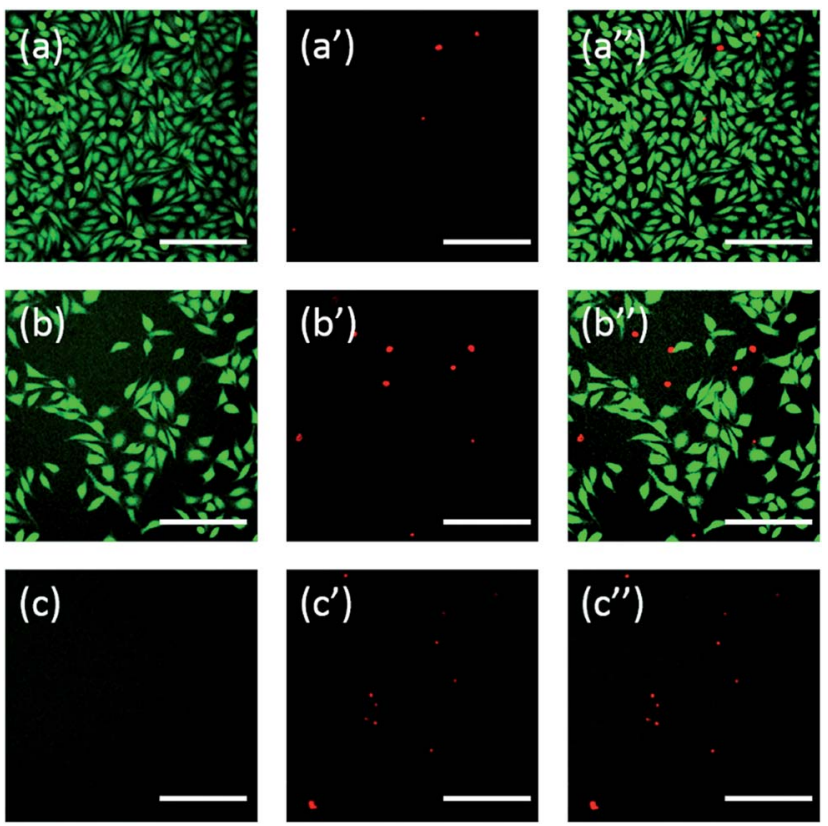

Fig. 6 Fluorescent images of L929 cells incubated with complete culture medium as control group (a, $\mathrm{a}^{\prime}$ and $\left.\mathrm{a}^{\prime \prime}\right), 20 \mathrm{mg} \mathrm{mL}^{-1}$ TEG (b, $\mathrm{b}^{\prime}$ and $\mathrm{b}^{\prime \prime}$ ) and $0.1 \mathrm{mg} \mathrm{mL}^{-1} \mathrm{mPEGA}-480$ (c, $\mathrm{c}^{\prime}$ and $\mathrm{c}^{\prime \prime}$ ) for $24 \mathrm{~h}$. Live cells showed green by FDA (excited by blue light $(a, b$ and $c)$ ), dead cells showed red by PI (excited by green light $\left(a^{\prime}, b^{\prime}\right.$ and $\left.\left.c^{\prime}\right)\right)$, mixed images were excited by blue light and green light $\left(a^{\prime \prime}, b^{\prime \prime}\right.$ and $\left.c^{\prime \prime}\right)$. Scale bar $=$ $200 \mu \mathrm{m}$.

\subsection{Mechanism study}

According to the cell viability experiments, the IC50 values of the PEG oligomers and PEG-based monomers to HeLa and L929 cells after $24 \mathrm{~h}$ culture were calculated and summarized (Table 1), suggesting that the PEG-based monomers are much more toxic to cells than the PEG oligomers, and the MPEGA has the highest cytotoxicity. The generation of ROS and decline of GSH in cells, two main mechanisms of cytotoxicity were therefore analysed to probe the possible reason of cytotoxicity.

3.3.1 Generation of ROS. Reactive oxygen species (ROSs) are chemical species containing oxygen in aerobic cell, including singlet oxygen, hydroxyl radical, superoxide and peroxides, etc. ${ }^{44}$ which are natural products of the intracellular metabolism and act important roles in cell signalling and other functions. Generally, the intracellular level of ROS is balanced but can dramatically increase under environment stress, leading to cell apoptosis. The generation of ROS is often considered as one of the most possible reasons of cytotoxicity for many biomedical materials. ${ }^{45-51}$ Thus, the ROS levels induced by TEG and MPEGA- 480 were measured respectively in current research through the DCFH-DA assay.

L929 cells were incubated with TEG, and the ROS levels at different time points $(0,0.5,1.0,1.5,2 \mathrm{~h})$ were detected according to our previous reports and shown in the Fig. 7. As an example, the ROS levels after incubation with different concentration TEG for $2 \mathrm{~h}$ were shown in Fig. 7A. It is clearly to see the ROS levels kept stable with low TEG concentration $(\leq 2 \mathrm{mg}$ $\mathrm{mL}^{-1}$ ), but significantly increased when TEG concentration is 
Table 1 The IC50 values ( $\mathrm{mg} \mathrm{mL}^{-1}$ ) for the PEG oligomers, PEG-based monomers to HeLa and L929 cells

\begin{tabular}{llllllllr}
\hline & TEG & PEG-400 & PEG-1000 & PEG-2000 & PEG-4000 & mPEGMA-500 & mPEGMA-950 & mPEGA-480 \\
\hline HeLa cells & 19.8 & 32.5 & 36.2 & 38.2 & 29.6 & 4.7 & 20.8 & 0.2 \\
L929 cells & 12.4 & 24.7 & 22.5 & 28.7 & 20.0 & 5.3 & 0.1
\end{tabular}
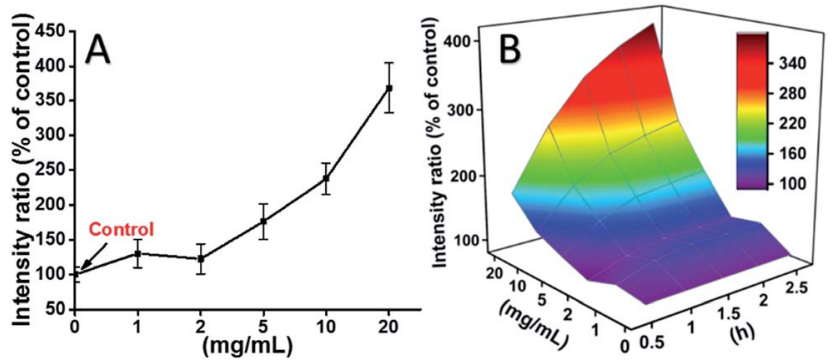

Fig. 7 Generation of ROS from L929 cells by the hydrolysis of DCFHDA after incubation with the TEG for $2 \mathrm{~h}(\mathrm{~A})$ and for multiple time (B)

higher than $2 \mathrm{mg} \mathrm{mL}^{-1}$, consistent with the result of cell viability experiment in Fig. 2B. Similarly, the figures of ROS level $v s$. TEG concentration at different time points were drawn and merged to get a 3D map (Fig. 7B). The maximum ROS levels were found at $2 \mathrm{~h}$ with $20 \mathrm{mg} \mathrm{mL}^{-1} \mathrm{TEG}$, an approximately $400 \%$ increased ROS level over control (ROS level $=100)$ was detected, resulting in the brightest fluorescence intensity. Those results suggest the generation of ROS is the possible mechanism of the cytotoxicity of TEG, and the high level of ROS induced by TEG might be the main reason for cell apoptosis.

The ROS levels induced by mPEGA-480 after $2 \mathrm{~h}$ were also tested (Fig. 8A). Different from TEG, mPEGA did not cause the quick increase of ROS in cells, only $\sim 170 \%$ ROS increase compared with the control was observed as the maximum. The 3D ROS level $v s$. mPEGA \& time (Fig. 8B) showed the ROS level induced by mPEGA-480 as a wave and the crest appeared at moderate concentration of mPEGA $\left(5 \mathrm{mg} \mathrm{mL}^{-1}\right)$, no significant generation of ROS can be observed, suggesting that the generation of ROS might only partly contribute to the cytotoxicity of mPEGA-480.

3.3.2 Declined of GSH. Reduced glutathione (GSH) is a tripeptide containing glutamic, cysteine and glycine. It is an
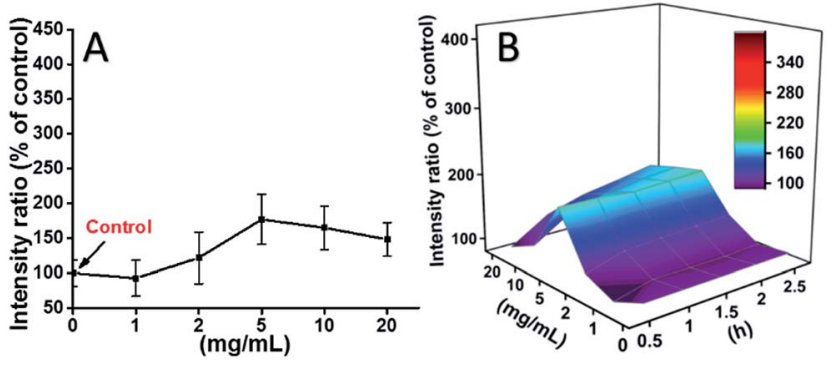

Fig. 8 Generation of ROS from L929 cells by the hydrolysis of DCFHDA after incubation with mPEGA-480 for $2 \mathrm{~h}$ (A) and for multiple time (B). important antioxidant in animals, plants and some bacteria. In this process, reduced glutathione is converted to oxidized glutathione (GSSG), two glutathione molecules connected via a disulfide bond. The decreased intracellular GSH may cause the increase of the level of intracellular ROS, leading to possible cytotoxicity. Thus, the decrease of GSH is also thought as one of the possible mechanisms of cytotoxicity. In the current research, the DNTB assay was employed to measure the intracellular GSH level. The GSH level of L929 cells were analysed after incubating the cells with TEG or MPEGA- 480 for $1 \mathrm{~h}$, cells in pure culture medium (100\%) were tested as the control (Fig. 9). No significant GSH decrease was observed when cells were incubated with TEG, implying the declined GSH might not be the cytotoxicity reason of TEG. On the contrary, when mPEGA-480 was incubated with cells, even at low concentration ( $\left.1 \mathrm{mg} \mathrm{mL}^{-1}\right)$, a sharp decline of the GSH value $(\sim 40 \%)$ was observed. With increased mPEGA-480's concentration, the GSH level quickly decreased to almost zero, suggesting that the cytotoxicity of mPEGA-480 might mainly stem from the declined GSH.

The reducing thiol group in GSH is an important antioxidation source in organisms. A possible mechanism for the cytotoxicity of mPEGA-480 is thereof attributed to the Michael addition reaction between thiol group and vinyl bond, leading to the broken intracellular redox equilibrium and cell apoptosis. Previous research suggested that the Michael addition between thiol and acrylate is much faster than that between thiol and methacrylate, ${ }^{52}$ which might be a reasonable cause for the different acute cytotoxicity between mPEGA-480 and MPEGMA-500.

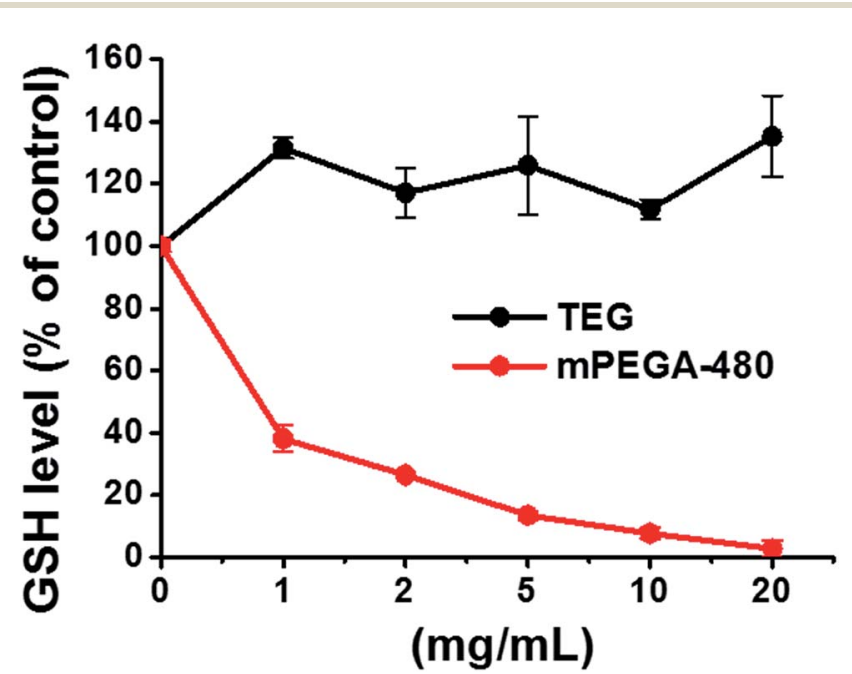

Fig. 9 Decline of GSH in L929 cells by the DNTB assay after incubating cells with the TEG and mPEGA-480. 


\section{Conclusions}

The cytotoxicity of PEG oligomers and PEG-based monomers to HeLa cells and L929 cells were evaluated for the first time. Concentration-dependent cytotoxicity of PEG oligomers and PEG-based monomers has been confirmed, and presented as IC50 values to HeLa cells and L929 cells. PEG-400, PEG-2000 seem almost non-cytotoxic in the current research. PEG-1000, PEG-4000 and mPEGMA-950 showed moderate cytotoxicity especially at high concentration. TEG and MPEGMA-500 showed significant cytotoxicity, and mPEGA-480 showed acute cytotoxicity. Moreover, cell types also influence the results of the cytotoxicity study, HeLa cells are more robust than L929 cells to tolerate PEG derivatives. These results about PEG derivatives cytotoxicity are preliminary but fundamental for their future biomedical application, more information about the cell response and behaviour to other PEG derivatives will be further investigated.

\section{Acknowledgements}

This research was supported by the National Science Foundation of China $(21574073,21534006)$.

\section{References}

1 M. V. Cleveland, D. P. Flavin, R. A. Ruben, R. M. Epstein and G. E. Clark, South. Med. J., 2001, 94, 478-481.

2 J. A. DiPalma, M. V. B. Cleveland, J. McGowan and J. L. Herrera, Am. J. Gastroenterol., 2007, 102, 1436-1441.

3 B. A. Erickson, J. C. Austin, C. S. Cooper and M. A. Boyt, J. Urol., 2003, 170, 1518-1520.

4 J. L. Cleland, S. E. Builder, J. R. Swartz, M. Winkler, J. Y. Chang and D. I. C. Wang, Bio/Technology, 1992, 10, 1013-1019.

5 Z. Liu, J. T. Robinson, X. M. Sun and H. J. Dai, J. Am. Chem. Soc., 2008, 130, 10876-10877.

6 J. M. Harris and R. B. Chess, Nat. Rev. Drug Discovery, 2003, 2, 214-221.

7 F. M. Veronese and G. Pasut, Drug Discovery Today, 2005, 10, 1451-1458.

8 M. J. Roberts, M. D. Bentley and J. M. Harris, Adv. Drug Delivery Rev., 2002, 54, 459-476.

9 F. M. Veronese, Biomaterials, 2001, 22, 405-417.

10 H. Zhang, T. Zhao, P. Duffy, Y. Dong, A. Ni Annaidh, E. O'Cearbhaill and W. Wang, Adv. Healthcare Mater., 2015, 4, 2260-2268.

11 Y. Dong, Y. Qin, M. Dubaa, J. Killion, Y. Gao, T. Zhao, D. Zhou, D. Duscher, L. Geever, G. C. Gurtner and W. Wang, Polym. Chem., 2015, 6, 6182-6192.

12 T. M. Allen, C. Hansen, F. Martin, C. Redemann and A. Yauyoung, Biochim. Biophys. Acta, Biomembr., 1991, 1066, 29-36.

13 Y. L. Zhang, L. Tao, S. X. Li and Y. Wei, Biomacromolecules, 2011, 12, 2894-2901.

14 Y. L. Zhang, B. Yang, L. X. Xu, X. Y. Zhang, L. Tao and Y. Wei, Acta Chim. Sin., 2013, 71, 485-492.
15 C. C. Luo, Y. H. Zhang, X. W. Zeng, Y. W. Zeng and Y. G. Wang, J. Colloid Interface Sci., 2005, 288, 444-448.

16 S. Dhar, F. X. Gu, R. Langer, O. C. Farokhzad and S. J. Lippard, Proc. Natl. Acad. Sci. U. S. A., 2008, 105, 17356-17361.

17 J. Manson, D. Kumar, B. J. Meenan and D. Dixon, Gold Bull., 2011, 44, 99-105.

18 X. Y. Zhang, C. K. Fu, L. Feng, Y. Ji, L. Tao, Q. Huang, S. X. Li and Y. Wei, Polymer, 2012, 53, 3178-3184.

19 X. Y. Zhang, J. F. Hui, B. Yang, Y. Yang, D. D. Fan, M. Y. Liu, L. Tao and Y. Wei, Polym. Chem., 2013, 4, 4120-4125.

20 D. Bontempo and H. D. Maynard, J. Am. Chem. Soc., 2005, 127, 6508-6509.

21 K. L. Heredia, Z. P. Tolstyka and H. D. Maynard, Macromolecules, 2007, 40, 4772-4779.

22 H. Hussain, K. Y. Mya and C. He, Langmuir, 2008, 24, 1327913286.

23 J. P. Magnusson, S. Bersani, S. Salmaso, C. Alexander and P. Caliceti, Bioconjugate Chem., 2010, 21, 671-678.

24 F. J. Xu, Y. L. Li, E. T. Kang and K. G. Neoh, Biomacromolecules, 2005, 6, 1759-1768.

25 L. L. Yu, L. Yao and K. Yang, J. Porous Mater., 2016, 23, 15811589.

26 S. Yuan, D. Wan, B. Liang, S. O. Pehkonen, Y. P. Ting, K. G. Neoh and E. T. Kang, Langmuir, 2011, 27, 2761-2774.

27 S. A, Q. Xu, D. Zhou, Y. Gao, J. M. Vasquez, U. Greiser, W. Wang, W. Liu and W. Wang, Polym. Chem., 2017, 8, 1283-1287.

28 H. F. Smyth, C. P. Carpenter and C. S. Weil, J. Am. Pharm. Assoc., 1950, 39, 349-354.

29 H. F. Smyth, C. P. Carpenter and C. S. Weil, J. Am. Pharm. Assoc., 1955, 44, 27-30.

30 D. E. Prentice and S. K. Majeed, Toxicol. Lett., 1978, 2, 119122.

31 H. Tominaga, M. Ishiyama, F. Ohseto, K. Sasamoto, T. Hamamoto, K. Suzuki and M. Watanabe, Anal. Commun., 1999, 36, 47-50.

32 Y. Li, Y. Zhang, F. Shi, L. Tao, Y. Wei and X. Wang, Colloids Surf., B, 2016, 149, 168-173.

33 B. Yang, Y. Zhang, X. Zhang, L. Tao, S. Li and Y. Wei, Polym. Chem., 2012, 3, 3235-3238.

34 H. Wang and J. A. Joseph, Free Radical Biol. Med., 1999, 27, 612-616.

35 I. K. Smith, T. L. Vieweller and C. A. Thorne, Anal. Biochem., 1988, 175, 408-413.

36 I. Rahman, A. Kode and S. K. Biswas, Nat. Protoc., 2006, 1, 3159-3165.

37 R. Jevprasesphant, J. Penny, R. Jalal, D. Attwood, N. B. McKeown and A. D'Emanuele, Int. J. Pharm., 2003, 252, 263-266.

38 A. K. Gupta and S. Wells, IEEE Trans. Nanobioscience, 2004, 3, 66-73.

39 D. Luo, K. Haverstick, N. Belcheva, E. Han and W. M. Saltzman, Macromolecules, 2002, 35, 3456-3462.

40 C. W. Chang, E. Bays, L. Tao, S. N. S. Alconcel and H. D. Maynard, Chem. Commun., 2009, 3580-3582. 
41 B. D. Fairbanks, P. A. Gunatillake and L. Meagher, Adv. Drug Delivery Rev., 2015, 91, 141-152.

42 T. Zhou, Y. Zhu, X. Li, X. Liu, K. W. K. Yeung, S. Wu, X. Wang, Z. Cui, X. Yang and P. K. Chu, Prog. Mater. Sci., 2016, 83, 191235.

43 K. H. Jones and J. A. Senft, J. Histochem. Cytochem., 1985, 33, 77-79.

44 M. Hayyan, M. A. Hashim and I. M. AlNashef, Chem. Rev., 2016, 116, 3029-3085.

45 A. Lankoff, W. J. Sandberg, A. Wegierek-Ciuk, H. Lisowska, M. Refsnes, B. Sartowska, P. E. Schwarze, S. MeczynskaWielgosz, M. Wojewodzka and M. Kruszewski, Toxicol. Lett., 2012, 208, 197-213.

46 Y. Chang, S.-T. Yang, J.-H. Liu, E. Dong, Y. Wang, A. Cao, Y. Liu and H. Wang, Toxicol. Lett., 2011, 200, 201-210.

47 X. Cai, J. Hao, X. Zhang, B. Yu, J. Ren, C. Luo, Q. Li, Q. Huang, X. Shi, W. Li and J. Liu, Toxicol. Appl. Pharmacol., 2010, 243, 27-34.
48 S. J. Park, Y. C. Park, S. W. Lee, M. S. Jeong, K.-N. Yu, H. Jung, J.-K. Lee, J. S. Kim and M.-H. Cho, Toxicol. Lett., 2011, 207, 197-203.

49 K. Pulskamp, S. Diabate and H. F. Krug, Toxicol. Lett., 2007, 168, 58-74.

50 A. M. Studer, L. K. Limbach, L. Van Duc, F. Krumeich, E. K. Athanassiou, L. C. Gerber, H. Moch and W. J. Stark, Toxicol. Lett., 2010, 197, 169-174.

51 T. Thurnherr, C. Brandenberger, K. Fischer, L. Diener, P. Manser, X. Maeder-Althaus, J.-P. Kaiser, H. F. Krug, B. Rothen-Rutishauser and P. Wick, Toxicol. Lett., 2011, 200, 176-186.

52 G. Li, R. K. Randev, A. H. Soeriyadi, G. Rees, C. Boyer, Z. Tong, T. P. Davis, C. R. Becer and D. M. Haddleton, Polym. Chem., 2010, 1, 1196-1204. 